\title{
Hubungan Pola Konsumsi Kudapan dengan Stunting pada Anak Kelas 1-2 SDN 036 Ujungberung Kota Bandung
}

\author{
Salma Raudhatusabrina, ${ }^{1}$ Herri S. Sastramihardja, ${ }^{2}$ Wiwiek Setiowulan ${ }^{3}$ \\ ${ }^{1}$ Prodi Pendidikan Dokter, ${ }^{2}$ Departemen Ilmu Farmakologi, ${ }^{3}$ Departemen Ilmu Kesehatan Anak Fakultas Kedokteran Universitas Islam Bandung
}

Latar belakang. Prevalensi anak dengan stunting di kota Bandung pada 2018 mencapai 25,8\%, melebihi ambang batas WHO (20\%). Rendahnya kualitas gizi asupan merupakan salah satu penyebab stunting. Konsumsi makanan kudapan dengan nilai gizi rendah pada anak di kota Bandung cukup tinggi, tetapi penelitian mengenai hubungan antara konsumsi kudapan dan stunting masih terbatas.

Tujuan. Mengetahui hubungan pola konsumsi kudapan dengan stunting pada anak kelas 1-2 SDN 036 Ujungberung Kota Bandung.

Metode. Penelitian analitik observasional dengan pendekatan potong lintang dilakukan pada 268 responden dengan teknik consecutive sampling. Analisis bivariat digunakan untuk mengetahui hubungan frekuensi konsumsi dan usia mulai mengonsumsi kudapan dengan stunting. Hasil. Frekuensi konsumsi kudapan berhubungan dengan kejadian stunting, p=0,032 (PR 1,61 (95\% CI 1,133-1,317)). Usia saat mulai mengonsumsi kudapan saja tidak berhubungan dengan kejadian stunting. Frekuensi konsumsi kudapan $\geq 1 \mathrm{x}$ per hari dan usia mulai mengonsumsi kudapan kurang dari 5 tahun berhubungan dengan kejadian stunting yang lebih tinggi, p<0,01 (PR: 2,02 (95\% CI 1,272-1,435)).

Kesimpulan. Terdapat hubungan bermakna antara pola konsumsi makanan kudapan dan stunting pada anak. Sari Pediatri 2021;23(2):121-8

Kata kunci: konsumsi makanan kudapan, stunting

\section{The Association of Snack Food Consumption Pattern with Stunting in Grade 1-2 Students of SDN 036 Ujungberung Bandung}

Background. The prevalence of stunting in the city of Bandung in 2018 reached 25.8\%, exceeding the WHO threshold (20\%). Low quality of nutritional intake is an important cause of stunting. Snack food consumption with low nutritional value is prevalent among children in Bandung, but research on the association of this certain habit with stunting is still limited.

Objective. To investigate the association between snack food consumption pattern and stunting in grade 1-2 students of SDN 036 Ujungberung, Bandung.

Method. Observational analytics research with a cross-sectional method using a consecutive sampling technique on 268 subjects was conducted. Bivariate analysis was used to determine the association of frequency and starting age of snack food consumption with stunting.

Results. The frequency of snack food consumption is associated with stunting, $\mathrm{p}=0,032$ (PR 1,61 (95\% CI 1,133-1,317)). The starting age of snack food consumption itself is not associated with stunting. Frequency of snack food consumption $\geq 1 \mathrm{x}$ per day and starting age below 5 years old are associated with higher stunting events, p<0,01 (PR: 2,02 (95\% CI 1,272-1,435)).

Conclusion. There is a significant relationship between snack food consumption patterns with stunting in grade 1-2 students of SDN 036 Ujungberung, Bandung. Sari Pediatri 2021;23(2):121-8

Keywords: snack food consumption, stunting.

Alamat korespondensi: Salma Raudhatusabrina. Program Pendidikan Kedokteran Fakultas Kedokteran Universitas Islam Bandung. Email: salmarsabrina@gmail.com 
Salma Raudhatusabrina dkk: Hubungan pola konsumsi kudapan dengan stunting

S eorang anak disebut stunting apabila mempunyai Z-Score tinggi badan menurut usia $(\mathrm{TB} / \mathrm{U})$ kurang dari -2 SD (standar deviasi) berdasarkan WHO Child Growth Standards (WCGS) yang disebabkan oleh faktor kekurangan nutrisi yang berlangsung kronis dan penyakit infeksi. ${ }^{1,2}$ Indonesia menempati urutan kelima tertinggi di dunia dalam hal prevalensi balita stunting setelah Pakistan (45\%), Kongo (43\%), India (39\%), dan Etiopia (38\%). ${ }^{3}$ Prevalensi balita stunting berdasarkan Riset Kesehatan Dasar (Riskesdas) 2018 untuk nasional adalah 30,8\%, sedangkan Provinsi Jawa Barat mencapai 31,1\%. ${ }^{4}$ Prevalensi stunting di Kota Bandung pada tahun yang sama adalah 25,8\%. Angka tersebut lebih rendah dari angka nasional, tetapi masih melampaui ambang batas yang ditoleransi oleh WHO, yaitu 20\%.

Stunting bukan hanya menyebabkan pertumbuhan tinggi badan terhambat, tetapi juga mengganggu perkembangan organ lain, terutama otak. Sel otak anak yang tumbuh normal mengalami percabangan yang ekstensif, sedangkan pada anak stunting percabangan sel otak bersifat terbatas, lebih pendek, dan abnormal. Anak dengan stunting berisiko mengalami gangguan perkembangan kognitif, yang pada akhirnya berdampak pada rendahnya kualitas kerja dan produktivitas ekonomi di usia dewasa. ${ }^{1}$

Anak perlu memperoleh asupan gizi yang seimbang guna mencapai pertumbuhan optimal, yaitu komposisi makanan berupa energi dari karbohidrat 50-65\%, protein $10-20 \%$, dan lemak $20-30 \%$ serta mengandung vitamin dan mikronutrien yang mencukupi. Gizi seimbang ini akan terpenuhi jika anak setiap hari mengonsumsi nutrisi beragam, meliputi sumber protein hewani, nabati, sayur, dan buah-buahan. ${ }^{6}$ Kekurangan kualitas dan kuantitas asupan gizi merupakan penyebab stuntingyang penting. ${ }^{7}$ Kondisi ini dapat mengakibatkan terhambatnya pertumbuhan dan terpakainya cadangan glikogen dan lemak tubuh sebagai sumber energi. ${ }^{8}$

Faktor penyebab malnutrisi pada anak di Indonesia, antara lain, pola konsumsi makan yang tidak sesuai, baik sejak usia $<12$ bulan maupun $\geq 12$ bulan. Penelitian Loya $\mathrm{dkk}^{9}$ terhadap balita stunting usia 6-12 bulan di Kabupaten Sumba Tengah, Provinsi Nusa Tenggara Timur, menyebutkan bahwa pola pemberian makan kepada balita stunting tidak sesuai dengan kebutuhan gizi subjek. Air Susu Ibu (ASI) tidak diberikan secara eksklusif, Makanan Pendamping-ASI (MP-ASI) diberikan terlalu dini, jenis MP-ASI tidak variatif, serta frekuensi pemberian makanan tidak sesuai dengan anjuran Kementerian Kesehatan.

Pada usia kanak-kanak, hal yang diduga berkontribusi terhadap buruknya kualitas asupan gizi pada anak di Indonesia ialah kebiasaan mengonsumsi makanan kudapan dengan kandungan gizi yang rendah. Secara umum, kudapan didefinisikan sebagai makanan/minuman berkalori yang dikonsumsi di antara waktu makan utama. Kebanyakan kudapan yang sering dikonsumsi anak bersifat padat kalori, minim kandungan gizi, dan tinggi kadar garam, gula, dan lemak (contohnya kue, biskuit, minuman berpemanis, dan keripik). ${ }^{10}$

Penelitian mengenai konsumsi makanan kudapan pada anak telah dilakukan, tetapi yang terkait dengan stunting masih terbatas. Green $\mathrm{dkk}^{11}$ melaporkan penelitiannya di Bandung bahwa 60\% anak usia 2435 bulan mengonsumsi makanan kudapan 3 kali atau lebih dalam sehari, terutama berupa biskuit manis, snack asin, dan minuman berpemanis. Penelitian Sekiyama $\mathrm{dkk}^{12}$ mengenai efek konsumsi makanan kudapan pada anak berusia 1-12 tahun di sebuah pedesaan Jawa Barat menemukan bahwa kelompok anak berusia $\geq 7$ tahun yang mengonsumsi kudapan lebih banyak memiliki nilai $Z$-score $\mathrm{TB} / \mathrm{U}$ lebih rendah dibandingkan kelompok yang mengonsumsi kudapan lebih sedikit.

Penelitian tersebut baru menunjukkan hubungan antara proporsi konsumsi kudapan dengan rata-rata Z-score $\mathrm{TB} / \mathrm{U}$, belum melihat hubungannya dengan kejadian stunting secara khusus. Tujuan penelitian ini adalah untuk mengetahui hubungan antara pola konsumsi kudapan dan kejadian stunting pada anak. Penelitian dilakukan di Sekolah Dasar Negeri 036 Kecamatan Ujungberung Kota Bandung dengan subjek penelitian siswa kelas 1 dan kelas 2 .

\section{Metode}

Penelitian analitik observasional dengan desain potong lintang dilakukan pada siswa kelas 1-2 Sekolah Dasar Negeri 036 Ujungberung di Kota Bandung. Pengambilan data dilakukan pada bulan Oktober 2019.

Kriteria inklusi adalah siswa kelas 1-2 di Sekolah Dasar Negeri 036 Ujungberung Kota Bandung yang orang tuanya bersedia menjadi responden penelitian. Informed consent diberikan oleh orang tua/wali anak. Kriteria eksklusi adalah: a) tidak berada di tempat 
pada waktu penyebaran kuesioner dilakukan; b) memiliki penyakit kronis seperti penyakit ginjal kronik, thalassemia, hipotiroid, diabetes melitus, yang diketahui melalui anamnesis; dan c) memiliki kelainan bawaan yang nyata berupa displasia tulang dan penyakit kelainan kromosom, seperti sindrom Down.

Dalam menilai penyebab stunting ini, terdapat beberapa faktor yang tidak diteliti, yaitu Berat Bayi Lahir Rendah (BBLR), orang tua stunting, penyakit infeksi berulang (batuk, pilek, dan diare), dan constituional delay of growth and puberty.

Definisi operasional untuk variabel bebas mencakup tiga hal, yaitu usia subjek mulai mengonsumsi makanan kudapan ( $<5$ tahun dan $\geq 5$ tahun), frekuensi konsumsi kudapan $(\geq 1 \mathrm{x} /$ hari dan $<1 \mathrm{x} /$ hari), serta potong lintang antara frekuensi konsumsi kudapan dan usia mulai mengonsumsi kudapan. Pengumpulan data dilakukan dengan memakai kuesioner.

Anak dikatakan stunting bila nilai Z-Score TB/U $<-2 S D$ dan memiliki tinggi badan normal bila Z-Score $\mathrm{TB} / \mathrm{U} \geq-2 \mathrm{SD}$. Data diperoleh dari hasil pengukuran antropometri yang dilakukan oleh Puskesmas Kecamatan Ujungberung pada bulan September dan Oktober 2019. Data diplot menggunakan kurva TB/U dari WHO growth reference untuk anak usia 5-19 tahun. ${ }^{13,14}$

Jumlah subjek ditentukan berdasarkan rumus sampel penelitian analitik kategorik tidak berpasangan, dengan rasio proporsi dua kelompok 3,95 berdasarkan prevalensi anak stunting di Kota Bandung. ${ }^{15}$ Didapatkan jumlah subjek sebanyak 268 siswa yang dikumpulkan dengan teknik consecutive sampling.

Dalam kuesioner ditanyakan mengenai karakteristik subjek, antara lain, usia anak, pendidikan ibu, pekerjaan ibu, dan penghasilan orang tua. Untuk pola konsumsi makanan kudapan ditanyakan mengenai frekuensi mengonsumsi makanan kudapan secara umum, frekuensi berdasarkan jenis makanan kudapan, usia saat mulai mengonsumsi kudapan, dan rata-rata pengeluaran per hari untuk membeli kudapan. Data kemudian dianalisis secara bivariat menggunakan uji Chi-Square untuk mengetahui hubungan antara pola konsumsi makanan kudapan dengan stunting. ${ }^{16}$

Penelitian ini telah memperoleh persetujuan dari Komisi Etik Penelitian Kesehatan (KEPK) Fakultas Kedokteran Universitas Islam Bandung (FK UNISBA) No. 112/Komisi Etik.FK/IV/2019.

\section{Hasil}

Jumlah subjek penelitian 268 siswa, mayoritas subjek berusia di atas 7 tahun $(83,6 \%)$ dan berjenis kelamin laki-laki (54,9\%). Responden penelitian (ibu) mayoritas berpendidikan setingkat SLTA ke atas $(68,3 \%)$ dan bekerja sebagai ibu rumah tangga $(71,3 \%)$. Pendapatan $42,9 \%$ responden berada di bawah pendapatan per kapita kota Bandung tahun 2019, yaitu Rp 2.250.000,(Tabel 1).

Proporsi stunting pada subjek penelitian adalah 25,4\% (Tabel 2). Dalam hal pola konsumsi kudapan, $70,9 \%$ subjek mulai mengonsumsi kudapan sejak usia kurang dari 5 tahun dan 54,5\% memiliki frekuensi konsumsi kudapan $\geq 1 \mathrm{x}$ per hari. Sementara yang memiliki kedua faktor risiko, yaitu mengonsumsi kudapan sejak usia kurang dari 5 tahun dengan frekuensi $\geq 1 \mathrm{x}$ per hari adalah $35,4 \%$ subjek (Tabel 2 ). Mayoritas responden $(77,9 \%)$ melaporkan jumlah pengeluaran per hari di atas $\mathrm{Rp} 5.000$,- untuk kudapan anak.

Tabel 3 memberi gambaran mengenai jenis kudapan yang paling sering dikonsumsi oleh subjek penelitian. Snack manis dalam kemasan merupakan kudapan yang paling sering dikonsumsi subjek, disusul oleh minuman berpemanis, snack asin dalam kemasan, dan jajanan tradisional. Sebanyak 44,8\% anak mengonsumsi snack manis dalam kemasan setidaknya $1 \mathrm{x} /$ hari, diikuti dengan proporsi sebesar 37,3\%, 26,9\%, dan 19,0\% untuk minuman berpemanis, snack asin dalam kemasan, dan jajanan tradisional.

Tabel 4 menunjukkan adanya hubungan antara frekuensi konsumsi kudapan dengan kejadian stunting pada subjek penelitian $(\mathrm{p}=0,032)$. Anak dengan frekuensi konsumsi kudapan $\geq 1 \mathrm{x} /$ hari memiliki Prevalence Ratio (PR) 1,61 (95\% CI 1,133-1,317) untuk mengalami stunting. Faktor usia mulai mengonsumsi kudapan saja tidak berhubungan dengan kejadian stunting. Tidak ada perbedaan yang bermakna antara usia $<5$ tahun maupun $\geq 5$ tahun saat anak mulai mengonsumsi kudapan dengan stunting ( $\mathrm{p}=0,052)$. Namun demikian, subjek yang memiliki kedua faktor risiko ini, yaitu frekuensi konsumsi kudapan $\geq 1 \mathrm{x} /$ hari dan mulai mengonsumsi makanan kudapan sejak usia $<5$ tahun, memiliki PR lebih tinggi untuk mengalami stunting dibandingkan yang dipengaruhi oleh faktor frekuensi konsumsi saja, yaitu sebesar 2,02 (95\% CI 1,272-1,435). Hal ini 
Tabel 1. Karakteristik subjek penelitian

\begin{tabular}{|c|c|c|}
\hline Variabel & Frekuensi (n) & Persentase (\%) \\
\hline \multicolumn{3}{|l|}{ Usia (tahun) } \\
\hline $6-<7$ & 44 & 16,4 \\
\hline $7-8$ & 182 & 67,9 \\
\hline$>8$ & 42 & 15,7 \\
\hline \multicolumn{3}{|l|}{ Jenis kelamin } \\
\hline Laki-laki & 147 & 54,9 \\
\hline Perempuan & 121 & 45,1 \\
\hline \multicolumn{3}{|l|}{ Pendidikan ibu } \\
\hline SD & 25 & 9,3 \\
\hline SLTP & 57 & 21,3 \\
\hline SLTA & 152 & 56,7 \\
\hline D3 & 12 & 4,5 \\
\hline S1 & 19 & 7,1 \\
\hline Lainnya & 3 & 1,1 \\
\hline \multicolumn{3}{|l|}{ Pekerjaan ibu } \\
\hline PNS/pegawai swasta & 28 & 10,4 \\
\hline Wiraswasta/pedagang & 27 & 10,1 \\
\hline Buruh & 18 & 6,7 \\
\hline Ibu rumah tangga & 191 & 71,3 \\
\hline Lainnya & 4 & 1,5 \\
\hline \multicolumn{3}{|l|}{ Penghasilan Keluarga } \\
\hline$<\operatorname{Rp} 2.250 .000$ & 115 & 42,9 \\
\hline$\geq \operatorname{Rp} 2.250 .000$ & 153 & 57,1 \\
\hline
\end{tabular}

Tabel 2. Pola konsumsi kudapan

\begin{tabular}{lcc}
\hline Variabel & Frekuensi (n) & Persentase (\%) \\
\hline Usia mulai mengonsumsi kudapan (tahun) & & \\
$\quad<5$ & 190 & 70,9 \\
$<2$ & 30 & 11,2 \\
$2-<5$ & 160 & 59,7 \\
$\quad \geq 5$ & 78 & 29,1 \\
Frekuensi konsumsi kudapan & & \\
$\quad \geq 1$ 1x per hari & 122 & 45,5 \\
$\quad<1$ x per hari & 146 & 54,5 \\
Frekuensi konsumsi kudapan $\geq 1$ x per hari & & \\
$\quad$ mulai usia $<5$ tahun & 95 & $35,4 \%$ \\
$\quad$ mulai usia $\geq 5$ tahun & 27 & $10,1 \%$ \\
Frekuensi konsumsi kudapan $<1$ x per hari & & \\
$\quad$ mulai usia $<5$ tahun & 95 & $35,4 \%$ \\
$\quad$ mulai usia $\geq 5$ tahun & 78 & $29,2 \%$ \\
Pengeluaran untuk membeli kudapan/hari & & \\
$\quad<$ Rp 5.000 & 59 & 22,0 \\
$\quad$ Rp 5.000 - Rp10.000 & 162 & 60,4 \\
$\quad>$ Rp 10.000 & 47 & 17,5 \\
\hline Total & 268 & 100 \\
\hline
\end{tabular}


Tabel 3. Frekuensi konsumsi kudapan menurut jenis

\begin{tabular}{|c|c|c|c|c|c|c|}
\hline \multirow[t]{2}{*}{ Jenis makanan kudapan } & $\begin{array}{l}\text { Tidak } \\
\text { Pernah }\end{array}$ & $\begin{array}{l}\text { Sangat } \\
\text { Jarang }\end{array}$ & Jarang & Sering & $\begin{array}{l}\text { Sangat } \\
\text { Sering }\end{array}$ & \multirow{2}{*}{$\begin{array}{c}\text { Total } \\
\%\end{array}$} \\
\hline & $\begin{array}{l}<1 \mathrm{x} \text { per } \\
\text { bulan }\end{array}$ & $\begin{array}{l}\text { 1-2x per } \\
\text { bulan }\end{array}$ & $\begin{array}{l}\text { 1-6x per } \\
\text { minggu }\end{array}$ & $\begin{array}{l}1-2 x \text { per } \\
\text { hari }\end{array}$ & $\begin{array}{l}\geq 3 \times \text { per } \\
\text { hari }\end{array}$ & \\
\hline \multicolumn{7}{|l|}{$\begin{array}{l}\text { Snack asin dalam kemasan (keripik } \\
\text { kentang, dll.) }\end{array}$} \\
\hline Frekuensi (n) & 5 & 28 & 160 & 72 & 0 & \multirow[t]{2}{*}{$268(100)$} \\
\hline Persentase (\%) & 1,9 & 10,4 & 59,7 & 26,9 & 0 & \\
\hline \multicolumn{7}{|c|}{$\begin{array}{l}\text { Snack manis dalam kemasan (permen, } \\
\text { coklat, biskuit, wafer, dll.) }\end{array}$} \\
\hline Frekuensi (n) & 2 & 20 & 126 & 115 & 5 & \multirow[t]{2}{*}{$268(100)$} \\
\hline Persentase (\%) & 0,7 & 7,5 & 47,0 & 42,9 & 1,9 & \\
\hline \multicolumn{7}{|c|}{$\begin{array}{l}\text { Jajanan tradisional (seblak, gorengan, } \\
\text { cilok, cakue, dll.) }\end{array}$} \\
\hline Frekuensi (n) & 18 & 61 & 138 & 48 & 3 & \multirow[t]{2}{*}{$268(100)$} \\
\hline Persentase (\%) & 6,7 & 22,8 & 51,5 & 17,9 & 1,1 & \\
\hline \multicolumn{7}{|l|}{ Minuman berpemanis } \\
\hline Frekuensi (n) & 6 & 36 & 126 & 89 & 11 & \multirow[t]{2}{*}{$268(100)$} \\
\hline Persentase (\%) & 2,2 & 13,4 & 47,0 & 33,2 & 4,1 & \\
\hline
\end{tabular}

Tabel 4. Hubungan antara pola konsumsi kudapan dan stunting

\begin{tabular}{|c|c|c|c|c|c|c|}
\hline \multirow{2}{*}{$\begin{array}{l}\text { Pola konsumsi makanan } \\
\text { kudapan }\end{array}$} & \multicolumn{2}{|c|}{ Stunting (\%) } & \multirow{2}{*}{ Jumlah } & \multirow{2}{*}{$\mathrm{p}$} & \multirow{2}{*}{$\mathrm{PR}$} & \multirow{2}{*}{$95 \% \mathrm{CI}$} \\
\hline & Ya & Tidak & & & & \\
\hline $\begin{array}{l}\text { Frekuensi } \\
\geq 1 \mathrm{x} / \mathrm{hari}\end{array}$ & $39(14,6)$ & $83(31,0)$ & $122(45,6)$ & & & \\
\hline$<1 \mathrm{x} / \mathrm{hari}$ & $29(10,8)$ & $117(43,7)$ & $146(54,4)$ & 0,032 & 1,61 & $1,133-1,317$ \\
\hline \multicolumn{7}{|l|}{$\begin{array}{l}\text { Usia mulai } \\
\text { mengonsumsi }\end{array}$} \\
\hline$<5$ tahun & $55(20,5)$ & $135(50,4)$ & $190(70,9)$ & & & \\
\hline$\geq 5$ tahun & $13(4,9)$ & $65(24,2)$ & $78(29,1)$ & 0,052 & & \\
\hline $\begin{array}{l}\text { Frekuensi } \geq 1 \mathrm{x} / \text { hari } \\
\text { mulai usia }<5 \text { tahun }\end{array}$ & $36(13,4)$ & $60(22,4)$ & $96(35,8)$ & $<0,01$ & 2,02 & $1,272-1,435$ \\
\hline $\begin{array}{l}\text { Frekuensi }<1 \mathrm{x} / \text { hari } \\
\text { mulai usia } \geq 5 \text { tahun }\end{array}$ & $32(11,9)$ & $140(52,2)$ & $172(64,2)$ & & & \\
\hline Jumlah & $68(25,4)$ & $200(74,7)$ & $268(100,0)$ & & & \\
\hline
\end{tabular}

menunjukkan, semakin sering dan semakin dini anak mulai mengonsumsi kudapan berhubungan dengan kejadian stunting yang semakin tinggi.

\section{Pembahasan}

Penelitian ini menunjukkan cukup tingginya proporsi anak yang mulai mengonsumsi kudapan sejak berusia kurang dari 5 tahun, yaitu mencapai 70,9\%. Bahkan, sebanyak 30 anak $(11,2 \%)$ telah mengonsumsi makanan kudapan sejak berusia kurang dari dua tahun. Hasil ini menunjukkan bahwa mayoritas anak telah mengonsumsi makanan kudapan sejak usia dini, bahkan pada periode emas kehidupannya. Pada periode ini, bayi mengalami proses pertumbuhan linier dan perkembangan otak yang sangat cepat. Kualitas nutrisi yang tidak adekuat usia sebelum dua tahun berpotensi mengganggu proses tersebut, yang ditandai oleh terjadinya stunting pada anak. ${ }^{17}$ 
Green $\mathrm{dkk}^{11}$ melaporkan konsumsi kudapan pada $81,6 \%$ anak usia $6-11$ bulan dan $91,9 \%$ anak usia 30-35 bulan di Bandung, lebih tinggi daripada angka penelitian ini. Hal ini kemungkinan menunjukkan semakin meningkatnya tren konsumsi kudapan pada anak usia balita. Alasan utama tingginya konsumsi kudapan ini antara lain karena kebiasaan orang tua mengikuti keinginan/permintaan anak $(48,4 \%)$ dan untuk menyenangkan anak (33,6\%). Karena ingin menyenangkan anak, orang tua cenderung mengikuti permintaan anak untuk mengonsumsi makanan kudapan sesuai keinginan anak.

Hasil penelitian ini menunjukkan bahwa snack dengan rasa manis merupakan kudapan yang paling sering dikonsumsi mayoritas subjek, disusul oleh minuman berpemanis, snack asin dalam kemasan, dan jajanan tradisional. Penelitian Green $\mathrm{dkk}^{11}$ juga memperlihatkan bahwa snack manis dalam kemasan dan minuman berpemanis merupakan jenis kudapan yang paling sering dikonsumsi anak. Jenis kudapan ini memiliki kadar gula yang tinggi, tetapi memiliki kandungan protein dan mikronutrien yang rendah. Menurut teori glukostatik, tingginya kadar gula darah dapat memberikan rasa kenyang sehingga menurunkan selera makan. ${ }^{18}$ Jenis makanan yang disukai berikutnya adalah snack asin, yang umumnya memiliki rasa gurih karena tambahan penyedap. Pola konsumsi sejak dini ini dapat mempengaruhi preferensi rasa pada anak, sehingga anak-anak kurang menyukai sayur dan buah maupun menu makanan yang dimasak di rumah.

Meskipun cukup tinggi proporsi responden yang memiliki pendapatan per kapita di bawah rata-rata Kota Bandung (42,9\%), mayoritas reponden $(77,9 \%)$ memiliki pengeluaran untuk jajan anak yang cukup besar, yaitu di kisaran Rp 5.000-Rp 10.000 per hari. Uang sebesar itu mungkin dapat digunakan oleh anak untuk membeli makanan kudapan yang bernilai gizi cukup. Namun demikian, faktor kandungan gizi di dalam kudapan mungkin tidak begitu dipertimbangkan oleh anak-anak.

Penelitian Amalia $\mathrm{dkk}^{19}$ tentang preferensi dan frekuensi konsumsi makanan kudapan pada anak sekolah dasar di Kecamatan Cijeruk, Kabupaten Bogor, mendukung hal itu. Amalia dkk menemukan bahwa alasan utama subjek dalam menyukai semua kelompok makanan kudapan adalah rasa (sekitar $60,0 \%$ responden), diikuti oleh harga (6,0-27,0\%). Sangat sedikit subjek yang menjadikan aspek gizi sebagai alasan dalam menyukai dan memilih makanan kudapan (0-6,0\%).
Penelitian Pries $\mathrm{dkk}^{20}$ terhadap anak usia 12-23 bulan di Kathmandu Nepal mengelompokkan subjek berdasarkan proporsi konsumsi kudapan dalam asupan hariannya, yaitu proporsi tinggi dan rendah. Anak dengan proporsi konsumsi kudapan yang tinggi berisiko memiliki asupan kalsium, zinc, vitamin $\mathrm{A}$, thiamin, riboflavin, vitamin $\mathrm{B} 6$, vitamin $\mathrm{B} 12$, dan folat yang lebih rendah. Studi ini memperlihatkan hubungan antara tingginya konsumsi kudapan dengan nilai $Z$ score TB/U yang lebih rendah, tetapi tidak menunjukkan hubungannya dengan stunting.

Penelitian Sekiyama dkk ${ }^{12}$ juga menunjukkan rendahnya asupan kalsium, vitamin $\mathrm{A}$, dan vitamin $\mathrm{C}$ pada kelompok dengan proporsi konsumsi kudapan yang tinggi dibandingkan kelompok dengan proporsi konsumsi kudapan yang rendah. Ditemukan nilai Z-score TB/U lebih rendah pada anak usia $\geq 7$ tahun dengan proporsi konsumsi kudapan yang tinggi dibandingkan yang rendah. Namun, tidak ada perbedaan nilai Z-score yang bermakna untuk anak usia $<7$ tahun. Hal ini mungkin menunjukkan bahwa semakin lama anak mengonsumsi kudapan dengan proporsi yang tinggi, semakin besar kemungkinan anak mengalami gangguan pertumbuhan linier.

Penelitian ini mengonfirmasi dugaan adanya hubungan antara frekuensi dan durasi anak mengonsumsi kudapan dengan kejadian stunting. Mayoritas subjek penelitian ini berusia usia $\geq 7$ tahun, serupa dengan karakteristik subjek dalam penelitian Sekiyama yang menunjukkan perbedaan Z-score TB/U berdasarkan proporsi konsumsi kudapan dalam total asupan hariannya. Meskipun penelitian ini tidak menggambarkan proporsi konsumsi makanan kudapan terhadap total asupan makanan harian, dapat diketahui bahwa anak dengan frekuensi konsumsi kudapan yang tinggi berrisiko 1,61 kali untuk mengalami stunting dibanding dengan yang frekuensi konsumsi kudapannya rendah. Bila kebiasaan mengonsumsi makanan kudapan tersebut dimulai pada usia yang lebih dini, yaitu $<5$ tahun, risiko stunting bahkan menjadi lebih tinggi, yaitu 2,02 kali.

Dari hasil penelitian ini diketahui mayoritas ibu berpendidikan setingkat SLTA ke atas (68,3\%), sehingga dapat dianggap memiliki pengetahuan cukup mengenai kebutuhan gizi anak. Faktor ekonomi dan pendidikan ibu tampaknya bukan penyebab utama rendahnya kualitas asupan makan anak. Penelitian Green dkk ${ }^{11}$ menunjukkan bahwa karena ingin menyenangkan anak, orang tua cenderung mengikuti permintaan anak untuk 
mengonsumsi makanan kudapan sesuai keinginan anak. Sementara itu, dari penelitiannya di Lembah Katmandhu, Sharma dkk ${ }^{21}$ menemukan sejumlah alasan mengapa para pengasuh memberi makanan kudapan komersial kepada anak, di antaranya karena makanan itu disukai anak-anak, mudah disediakan, dan mudah disuapkan. Di samping itu, pengasuh mengikuti kebiasaan setempat, yaitu ketika orang dewasa lazim memberi hadiah kepada anak-anak berupa makanan kudapan. Oleh karena itu, pola konsumsi makan anak yang berhubungan dengan pola asuh, kebiasaan di keluarga, dan kultur di masyarakat berperan sangat penting dan perlu menjadi pertimbangan dalam merencanakan program intervensi untuk meningkatkan kualitas asupan bagi anak.

\section{Kesimpulan}

Frekuensi konsumsi makanan kudapan berhubungan dengan stunting pada anak. Usia saat mulai mengonsumsi makanan kudapan tidak berhubungan dengan stunting. Namun, bila digabungkan dengan faktor frekuensi konsumsi, usia yang lebih dini saat mulai mengonsumsi makanan kudapan berhubungan dengan kejadian stunting yang lebih tinggi. Perlu dilakukan penelitian lebih lanjut mengenai pola belanja dan pola asuh di rumah tangga sehubungan dengan pola konsumsi makan anak sejak dini agar dapat ditentukan metode intervensi yang paling tepat untuk mencegah terjadinya stunting pada anak sejak usia dini.

\section{Daftar pustaka}

1. World Health Organization. Reducing stunting in children: equity considerations for achieving the global nutrition targets 2025 (monograf di internet). Geneva: World Heal Organ; 2018 (diunduh 11 Januari 2019). Didapat dari: apps.who.int/ iris/bitstream/10665/.../9789241 513647-eng

2. World Health Organization. Nutrition landscape information system (NLIS) country profile indicators: interpretation guide (monograf di internet). Geneva: World Heal Organ; 2010 (diunduh 20 Januari 2019). Didapat dari: https://apps.who. int/iris/bitstream/handle/10665/44397/97892 41599955_eng. pdf?:sequence $=1$

3. Tim Nasional Percepatan Penanggulangan Kemiskinan (TNP2K). Gerakan nasional pencegahan stunting dan kerjasama kemitraan multi sektor (materi presentasi di internet). Jakarta: Kantor Sekr Wapres RI; 2018 (diunduh
6 Januari 2019):3-7. Didapat dari: tnp2k.go. id/.../Sesi\%20 2_01_20181122\%20gerakan\%20nasional\%20pencegahan $\% 20$.

4. Badan Penelitian dan Pengembangan Kesehatan. Hasil utama riskesdas 2018 (materi presentasi di internet). Jakarta: Kemenkes RI; 2018 (diunduh 8 Januari 2019). h10-1. Didapat dari: https://kesmas.kemkes.go.id/assets/upload/ dir_519d41d8cd98f00/ files/Hasil-riskesdas-2018_1274.pdf.

5. Dinas Kesehatan Kota Bandung. Tekan angka stunting, kader gizi bentuk Forkagi. dinkes.bandung.go.id (homepage di internet). Rabu, 23 Mei 2018 (diakses pada 8 Februari 2019). Didapat dari: https://dinkes.bandung. go.id/dashboard. php?page $=$ pengumumane $i d=43$

6. Kementerian Kesehatan RI. Pedoman gizi seimbang (monograf di internet). Jakarta: Kemenkes RI; 2014 (diunduh 2 Feb 2019). Didapat dari: gizi.depkes.go.id/download/pedoman $\% 20$ gizi/pgs\%20ok.pdf

7. Tridjaja B, Short stature (perawakan pendek): diagnosis dan tata laksana. Dalam: Trihono PP, Djer MM, Sjakti HA, Hendrarto TW, Prawitasari T, penyunting. Best practices in pediatrics (monograf di internet). Jakarta: Ikatan Dokter Anak Indonesia Cabang DKI Jakarta; 2013 (diunduh 10 Februari 2019). h 118. Didapat dari: http://fk.ui.ac.id/wp-content/uploads/2016/01/ Buku-PKB-IDAI-Jaya-X.pdf

8. Par'i HM, Wiyono S, Harjatmo TP. Penilaian status gizi (monograf di internet). Jakarta: Pusat Pendidikan Sumber Daya Manusia Kesehatan; 2017 (diunduh 4 Februari 2019). Didapat dari: bppsdmk.kemkes.go.id/ pusdiksdmk/wp.../ PENILAIAN-STATUS-GIZI-FINAL-SC.pdf

9. Loya RRP, Nuryanto. Pola asuh pemberian makan pada balita stunting usia 6-12 bulan di Kabupaten Sumba, Nusa Tenggara Timur (serial online). J Nutr Coll 2017;6:83-95.

10. Hess JM, Jonnalagadda SS, Slavin JL. What is a snack, why do we snack, and how can we choose better snacks? A review of the definitions of snacking, motivations to snack, contributions to dietary intake, and recommendations for improvement (serial online). Adv Nutr 2016;7:466-75.

11. Green MK, Hadihardjono DN, Pries AM, Izwardy D, Zehner E, dan Huffman SL. High proportions of children under 3 years of age consume commercially produced snack foods and sugar-sweetened beverages in Bandung City, Indonesia (serial online). Matern Child Nutr 2019;15 Suppl4:1-14.

12. Sekiyama M, Roosita K, Ohtsuka R. Snack foods consumption contributes to poor nutrition of rural children in West Java, Indonesia (serial online). Asia Pac J Clin Nutr 2012;21:558-67.

13. WHO. Height-for-age girls 5-19 years (z-scores) chart. World Heal Organ 2007 (diunduh 8 Januari 2019). Didapat dari: https://www.who.int/tools/growth-reference-data-for-5to19-years/ indicators/height-for-age.

14. WHO. Height-for-age boys 5-19 years (z-scores) chart. World Heal Organ. 2007 (diunduh 8 Januari 2019) Didapat dari: https://www.who.int/tools/growth-reference-data-for-5to19-years/ indicators/height-for-age..

15. Dahlan MS. Besar sampel dalam penelitian kedokteran dan kesehatan. Edisi ke-4. Jakarta: Epidemiologi Indonesia; 2016.h.324-7. 
16. Dahlan MS. Analisis multivariat regresi logistik: disertai praktik dengan program SPSS dan Stata. Jakarta: Epidemiologi Indonesia; 2012.

17. WHO. Stunting in a nutshell (article on the Internet). World Heal Organ; 2014 (diunduh November 2019). Didapat dari: https://www.who.int/nutrition/healthygrowthproj_stunted_ videos/en/.

18. Chaput J-P, Tremblay A. The glucostatic theory of appetite control and the risk of obesity and diabetes (serial online). Int J Obes 2009;33:46-53.

19. Amalia L, Endro OP, Damanik MRM. Preferensi dan frekuensi konsumsi makanan jajanan pada anak sekolah dasar di
Kecamatan Cijeruk, Kabupaten Bogor (serial online). J Gizi dan Pangan 2012;7:119-26.

20. Pries AM, Rehman AM, Filteau S, Sharma N, Upadhyay A, Ferguson EL. Unhealthy snack food and beverage consumption is associated with lower dietary adequacy and length-for-age z-scores among 12-23-month-olds in Kathmandu Valley, Nepal (serial online). J Nutr 2019;14:1843-51.

21. Sharma N, Ferguson EL, Upadhyay A, Zehner E, Filteau S, Pries AM. Perceptions of commercial snack food and beverages for infant and young child feeding: a mixed-methods study among caregivers in Kathmandu Valley, Nepal (serial online). Matern Child Nutr 2019;15:e12711. 